\title{
ESTROGEN RECEPTOR TRANSLOCATION AND ORNITHINE AMINOTRANSFERASE INDUCTION BY ESTRADIOL IN RAT KIDNEY
}

\author{
Chung Wu
}

Departments of Biological Chemistry and Internal Medicine The University of Michigan Medical School

Ann Arbor, Michigan $₫ 8109$

Received June 25, 1979

\section{Summary}

Injection of a hyperphysiological dose of $17 \beta$-estradiol to the rat elicits a translocation of the cytoplasmic estrogen receptor in the kidney. This is followed, a few hours later, by an increase in the rate of ornithine aminotransferase synthesis. This increase, in turn, causes the enzyme activity to rise also a few hours later.

Growth of rat kidney tumor MK3 has delayed the induction of ornithine aminotransterase by $17 \beta$-estradiol in the host kidney. However, the enzyme is not inducible in several normal tissues where the activity is high and where concentrations of estrogen receptor greatly exceed that in rat kidney. These observations suggest certain possible mechanisms of the inductive process.

\section{Introduction}

Most biochemical studies on estrogens have been done with target tissues. such as uterus and oviduct, as indicated by recent reviews (1-4). Although target tissues provide a logical approach to study estrogenic actions on biosynthetic processes, it is difficult to study a single biochemical effect without having the hormone set off at the same time a series of reactions affecting the overall metabolism of the tissues, which might in turn modify the effect being studied. The use of non-target tissues, on the other hand, alleviates this complication, but suffers from the apparent lack of parameters that can serve as a probe to study estrogenic actions. Hence, we considered the enhancement of ornithine aminotransferase (OAT) (EC 2.6.1.13) activity by estrogens in rat kidney as a useful biochemical model to study the estrogenic action on an enzyme synthesis in a non-target tissue (5).

We have demonstrated the presence of a high affinity estrogen binding protein in the kidney cytosol and a correlation between the ability of several estrogens to increase OAT activity and their ability to compete with ${ }^{3} \mathrm{H}$-estradiol for the binding protein in the kidney cytosol (5). Recently, we have 
determined that the increase in OAT activity resulted from an increase in the concentration of enzyme molecules (6). Moreover, some antiestrogens could induce the enzyme also.

Apparently, estradiol receptor plays an important role in OAT induction in rat kidney. In this communication, we report the results which show a correlation of this enzyme induction with the translocation of the cytoplasmic estrogen receptor in rat kidney. Also presented are observations on OAT induction in kidney of rats bearing a kidney tumor and in hamster and other ral Lissues.

\section{Materials and Methods}

Animals. Ovariectomized rats of the Sprague-Dawley strain weighing 150$200 \mathrm{~g}$ were used for experiments at least 2 weeks after surgery. Rats bearing kidney tumor MK3 were of the Buffalo strain and the tumor was transplanted $\mathrm{i} . \mathrm{m}$. The tumor had a low growth rate and the animals were used in experiments after 6 months of tumor growth without ovariectomy. Syrian golden hamsters were of the outbred strain LVG:LAK. I'he animals were killed by decapitation under light ether anesthesia.

Estradiol injection. $17 \beta-$ Estradiol was dissolved in sesame oil $(500 \mu \mathrm{g} / \mathrm{ml})$ and injected $\mathrm{i} . \mathrm{m}$. Two dosage schedules were used. For study of OAT synthesis and estrogen receptor concentration in rat kidney, a single injection of a suboptimal dose of $50 \mu \mathrm{g} / 250 \mathrm{~g}$ body weight was given at different time intervals before assay. For comparison of OAT activity in different tissues of rats and hamsters, the estradiol dose was $50 \mu \mathrm{g} / \mathrm{l} 100 \mathrm{~g}$ body weight either given in a single injection $16 \mathrm{hr}$ before assay or given in multiple injections every $48 \mathrm{hr}$ with the last injection being $16 \mathrm{hr}$ before assay.

Pieparation of cylosol. The procedure for the preparation of rat kidney cytosol for the estrogen receptor assay is generally based on the procedure of Katzenellenbogen et al. (7) for the uterine cytoplasmic estrogen receptor. All procedures, unless otherwise stated, were carried out at $0-4^{\circ}$. Rat kidney, usually $700 \mathrm{mg}$, was cut into small pieces and homogenized in TED buffer (10 mM Tris- $\mathrm{HCl}, 1.5 \mathrm{mM}$ EDTA, $0.5 \mathrm{mM}$ dithiothreitol, $\mathrm{pH} 7.4$ ) with intermittent cooling in a motor-driven unground glass tissue grinder fitted with a Teflon pestle run at about $160 \mathrm{rpm}$ for $2 \mathrm{~min}$. The homogenate equivalent to $50 \mathrm{mg}$ tissue/ $\mathrm{ml}$ was centrifuged at $800 \times \mathrm{g}$ for $10 \mathrm{~min}$. The supernatant fluid from the nuclear pellet, which contained no significant amounts of DNA, was centrifuged at $110,000 \times \mathrm{g}$ for $1 \mathrm{hr}$. The cytosol was treated with a $10 \%$ volume of a dextran-charcoal suspension $(5 \%$ Norit $A$ and $0.5 \%$ dextran in TED buffer) with intermittent shaking for $15 \mathrm{~min}$ and then centrifuged at $1,500 \mathrm{xg}$ for 7 min to remove the charcoal.

Estrogen receptor assay. The charcoal-treated cytosol was used for the estrogen receptor assay as follows. From 0.1 to $0.5 \mathrm{ml}$ of the cytosol were added to tubes containing $12 \mathrm{nM}^{3} \mathrm{H}$-estradiol $(60 \mathrm{Ci} / \mathrm{mmol}$, New England Nuclear) (for total binding) or $12 \mathrm{nM}{ }^{3} \mathrm{H}$-estradiol plus $1.2 \mu \mathrm{M}$ unlabeled estradiol (for non-specific binding) in a volume of $0.5 \mathrm{ml}$. The estradiol solutions were made in ethanol and aliquots were dried under a stream of nitrogen 
in the tubes before addition of cytosol and TED buffer. Specific estrogen receptor sites were estimated by a difference between the total and the nonspecific bindings.

The tubes were incubated at $28^{\circ}$ for $20 \mathrm{hr}$. At the end of incubation, the tubes were cooled at $4^{\circ}$ for $30 \mathrm{~min}$, treated with $50 \mu \mathrm{l}$ of the dextran-charcoal suspension for 15 min with intermittent mixing, and centrifuged at $1,500 \times \mathrm{g}$ for $7 \mathrm{~min}$. The supernatant fluids were used for counting. The counting was done as cescribed before (6) and had an efficiency of $32 \%$ for ${ }^{3} \mathrm{H}$. The onestep incubation does not distinguish the uncharged sites from those initially charged with estradiol $(7,8)$, but determines the sum of both sites.

Immunochemical assay of OAT. The same kidneys that were used for estrogen receptor assay were also used for determination of the rate of OAT synthesis in slices by an immunochemical procedure described earlier (6). Briefly, the incorporation of ${ }^{14} \mathrm{C}$-leucine into $\mathrm{OAT}$ in kidney slices was determined by precipitatior. with an anti-OAT serum. Radioactivities in OAT and in soluble proteins were counted. The results are expressed as a ratio of $\mathrm{cpm}$ OAT $\mathrm{x} 100$ to $\mathrm{cpm} / \mathrm{mg}$ protein.

Other methods. OAT activity was assayed as before (6) in tissue homogenates. The enzyme activity is expressed as units/g wet tissue. One unit of activity is the amount of enzyme that will cause the formation of $1 \mu$ mole of glutamate $\gamma$-semialdehyde/ hr at $37^{\circ}$. Protein was determined by the procedure of Lowry et al. (9) with bovine serum albumin as standard. DNA determination followed the diphenylamine method of Burton (10).

\section{Results and Discussion}

To ascertain that specific estrogen receptor sites determined in the cytoplasmic extracts were proportional to the amounts of kidney tissue used, we determined their relationship in the kidney of an ovariectomized rat. Fig. 1

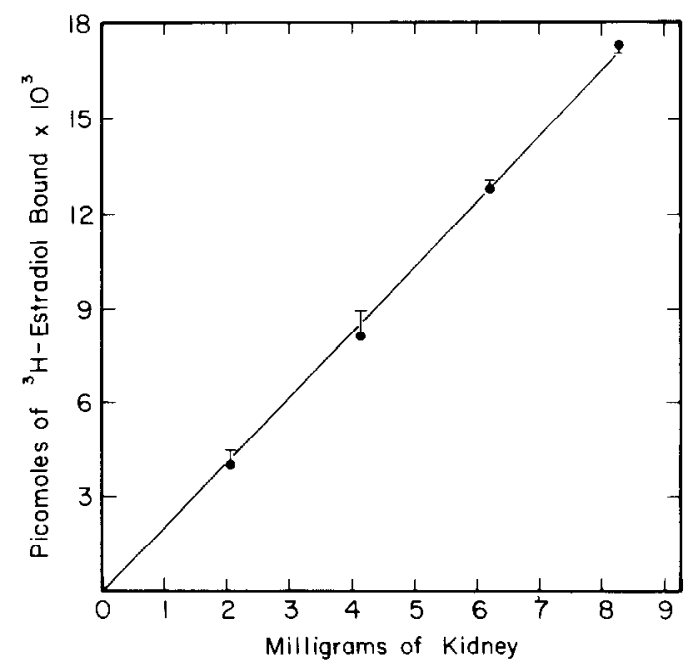

Fig. I. Linear relationship between picomoles of ${ }^{3} \mathrm{H}$-estradiol specifically bound to the cytoplasmic receptor and milligrams of kidney of an ovariectomized rat. Vertical lines show the standard deviations from the means. 


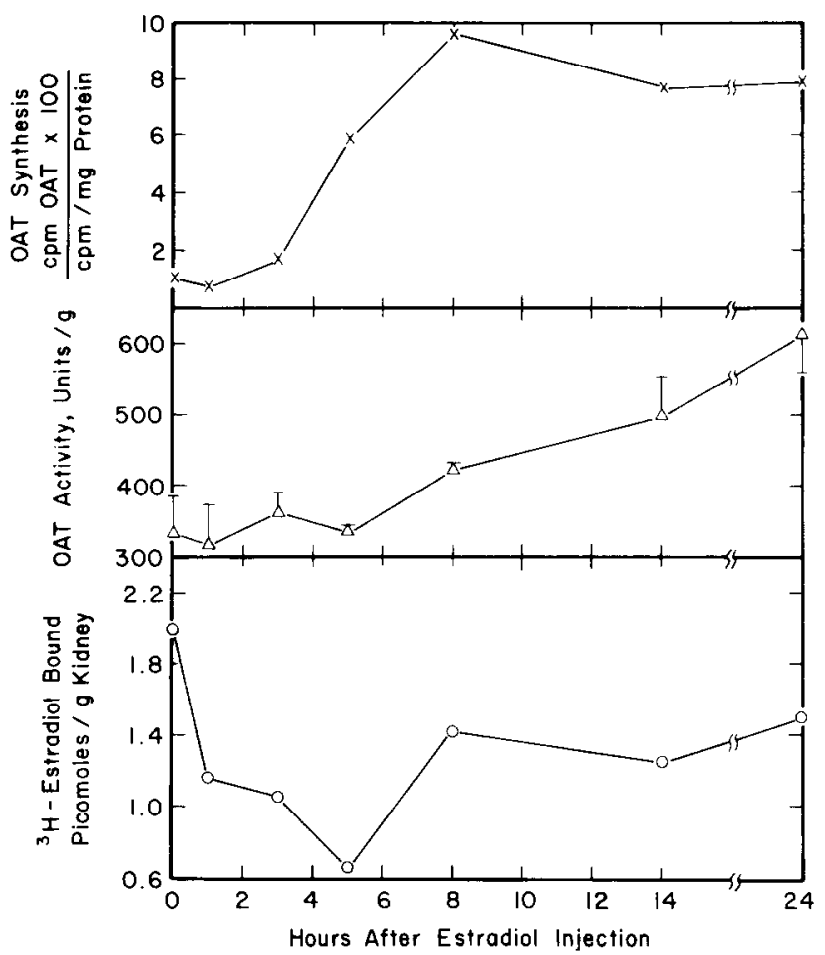

Fig. 2. Changes in specific cytoplasmic estrogen receptor binding sites, relative rate of OAT synthesis, and OAT activity following estradiol injection to ovariectomized rats. Estradiol dissolved in sesame oil was injected i.m. at $50 \mu \mathrm{g} / 250 \mathrm{~g}$ body weight. The 3 parameters were determined at various time intervals after the injection. Vertical lines in the middle curve show the standard deviations from the means. For details, see text.

shows the linearity between picomoles of ${ }^{3} \mathrm{H}$-estradiol specifically bound to the estrogen receptor and milligrams of kidney tissue used. There were 2.06 pmoles of specifically bound ${ }^{3} \mathrm{H}$-estradiol in the cytosol from $\mathrm{l} \mathrm{g}$ of kidney (31.1 pmoles/g cytoplasmic protein or 0.69 pmoles/ mg DNA). Hence, the concentration of estrogen receptor in the kidney cytosol is about $20 \%$ of that in the uterine cytosol, 3.20 pmoles/mg DNA (8).

The non-specific binding in rat kidney cytosol generally amounted to $80 \%$ of the total-- a very high percentage compared to that found in rat uterine cytosol (7) and probably characteristic of non-target tissues (11). We have tried to assay the kidney nuclear receptor sites with ethanol extraction (12) and with $\mathrm{KCl}$ extraction alone or with protamine (8), but the results were inconsistent.

We studied the correlation between OAT synthesis and activity and the translocation of estrogen receptor. f'ig. 2 shows how the relative rate of OAT syn- 
thesis can be correlated with changes in the concentration of the cytoplasmic estrogen receptor and in OAT activity in kidney following an $1 . \mathrm{m}$. injection of estradiol in sesame oil. To minimize the amount of estradiol given, a dosage suboptimal for OAT activity increase was chosen. For the determination of OAT synthesis and specific estrogen binding sites, kidneys from 2 to 5 rats were often pooled with each contributing an equal share. Hence, these 2 curves show average points only. In some instances, determinations with individual kidneys were made for specific estrogen binding sites and the standard dcviations from the means were similar to those shown in Fig. 1.

The upper curve in Fig. 2 shows that a 6 -fold increase in the relative rate of OAT synthesis took place $5 \mathrm{hr}$ after estradiol injection. The increase continued to its peak at 10 -fold in the 8 th $\mathrm{hr}$. Thereafter, the rate tapered off slightly, but remained unabated with an 8 -fold increase through the 24 th hr. The lower curve shows changes in the cytoplasmic estrogen receptor concentration relative to time after estradiol injection. There was a significant decrease in the first hr following injection and the decrease continued until it reached the nadir in the 5 th $\mathrm{hr}$. A partial repletion of the receptor began after this time and a concentration about $70 \%$ of the control value was maintained between the 8 th and 24 th hr. A comparison of these 2 curves indicates that the first increase in the relative rate of OAT synthesis did not occur until some 4 hr after the cytoplasmic receptor had been translocated into the nucleus. Moreover, the peak of the rate increase lagged behind the largest depletion of the cytoplasmic receptor by about the same interval of time. These results suggest that translocation of the cytoplasmic receptor into the nucleus is a prerequisite for OAT induction and the induction takes place 3-4 hr following the initial translocation. Apparently, the increased rate of OAT synthesis can be maintained for many hours when the cytoplasmic receptor is partially depleted, presumably through a gradual but continuous translocation.

A discussion may be made at this point of the shape of the specific ${ }^{3} \mathrm{H}-$ estradiol binding curve for rat kidney, which is quite different from that for rat uterus (8). In the latter, a physiological dose of estradiol in saline was injected i.p., the cytoplasmic receptor was shown to have reached negligible levels within $20 \mathrm{~min}$ after the injection and a corresponding increase in the nuclear receptor was found at the same time. By the end of $24 \mathrm{hr}$, the cytoplasmic receptor level had returned to normal. The lower curve in Fig. 2 shows 
that at no time did the cytoplasmic receptor level approach zero and it was not fully repleted $24 \mathrm{hr}$ after the injection. Perhaps, no comparison can be made of these two situations, not only because of differences in tissues and dosages of estradiol, but also because of differences in solvents and routes of injection employed.

Another observation we made worthy of note is the constancy of the rate of ${ }^{14} \mathrm{C}$-leucine incorporation into soluble proteins. Despite the several-fold increase in the rate of OAT synthesis after estradiol, the rate of protein synthesis was not appreciably affected. The cpm/ nig protein ranged between 2,500 and 3,500, indicating that the hormone affects OAT synthesis, but does not effect an increase in protein synthesis in general, thereby making its effect on OAT free from a multitude of changes that follow the hormone administration to a target tissue (2).

The middle curve in Fig. 2 shows OAT activity changes with time following estradiol injection. There was no significant increase in the first $5 \mathrm{hr}$. From the 8 th hr on, there was a gradual rise in the enzyme activity, which doubled the basal level in $24 \mathrm{hr}$. Apparently, the increase in OAT activity was the last of the 3 parameters to occur, since it lagged behind the rate increase by a few hours. Moreover, despite the several-fold increase in the relative rate of OAT synthesis in vitro, there was only a 2 -fold increase in OAT activity. We offer two explanations. First, it is not certain that OAT synthesis would proceed at the same rate in vivo. Second, Ip et al. (13) have reported the half-life of OAT in rat liver to be 1.9 days. If this is also true of the kidney enzyme, the activity determined at any given time interval after estradiol injection probably reflects a large portion of enzyme molecules that have been synthesized before estradiol administration.

In short, we have observed a temporal relation among the 3 parameters studied. After an injection of estradiol to the rat, the decline of the cytoplasmic estrogen receptor in the kidney precedes the increase in OAT synthesis by a few hours, which in turn precedes the increase in OAT activity by a few hours.

Because of our interest in the altered inducibility of enzymes during carcinogencsis $(14,15)$, we studicd the estradiol effect on $\mathrm{O} N \mathrm{~T}$ in the kidney of rats bearing kidney tumor MK3. A higher dose of estradiol was used in these experiments than in the preceding ones and OAT activity increase was also much 
TABLE I

Effect of Estradiol on Ornithine Aminotransferase in Rat and Hamster Tissues

\begin{tabular}{|c|c|c|c|c|}
\hline Animals & $\begin{array}{l}\text { Estradiol } \\
\text { treatment }\end{array}$ & Kidney & $\begin{array}{c}\text { OAT activity } \\
\text { Liver }\end{array}$ & Uterus \\
\hline \multicolumn{5}{|l|}{ Rats } \\
\hline \multirow[t]{2}{*}{ Normal, female } & None & $353 \pm 33$ & $169 \pm 33$ & $13.2 \pm 2.2$ \\
\hline & $\begin{array}{l}16 \mathrm{hr} \\
3 \text { days }\end{array}$ & $1,168 \pm 285$ & $144 \pm 12$ & \\
\hline \multirow{3}{*}{$\begin{array}{l}\text { Tumor-bearing, } \\
\text { female }\end{array}$} & None & $233 \pm 87$ & & \\
\hline & $16 \mathrm{hr}$ & $298 \pm 38$ & & \\
\hline & 5 days & $1,115 \pm 260$ & & \\
\hline \multirow{2}{*}{$\begin{array}{l}\text { Tumor-bearing, } \\
\text { male }\end{array}$} & None & $169 \pm 52$ & $129 \pm 22$ & \\
\hline & 5 days & $1,186 \pm 226$ & $103 \pm 24$ & \\
\hline \multicolumn{5}{|l|}{ Hamsters } \\
\hline \multirow[t]{3}{*}{ Normal, female } & None & $78.6 \pm 7.9$ & $87.1 \pm 23.3$ & \\
\hline & $16 \mathrm{hr}$ & $75.2 \pm 17.5$ & & \\
\hline & 5 days & $69.4 \pm 9.8$ & $79.2 \pm 11.4$ & \\
\hline Ovariectomized & None & $68.1 \pm 6.3$ & & \\
\hline
\end{tabular}

Rats bearing kidney tumor MK3 were used 6 months after transplantation withol:t ovariectomy. Ovariectomized hamsters were used 2 weeks after surgery. Estradiol was injected i.m. at $50 \mu \mathrm{g} / 100 \mathrm{~g}$ body weight, either in one or multiple injections. OAT activity is expressed in units/g tissue. There were $3-6$ animals in each group.

higher. As shown in Table 1, OAT in the host kidney did not respond to estradiol in 16 hr as did the enzyme in normal kidney. However, responsiveness of OAT to estradiol was not completely absent from the host kidney, because prolonged estradiol treatment for 5 days did raise the enzyme activity to the same level as observed in normal kidney, namely, from about 200 to over 1,100 units/g. Hence, the presence of the tumor delays the responsiveness of OAT tc estradiol, but does not abolish it. On the other hand, like the enzyme in kidney tumor MK3 (14), OAT in liver and uterus of normal rats was unresponsive to estradiol. Li et al. (11) have reported that the concentration of estrogen receptor was higher in rat liver cytosol than in rat kidney cytosol. Apparently, the inability of estradiol to induce OAT in liver and uterus cannot be due to low concentrations of estrogen receptor in these tissues.

We then considered the possibility that the effect was lissue-specific. Since harnster kidney cytosol contains much higher concentrations of estrogen receptor than rat kidney cytosol (11), we studied how estradiol affected OAI in hamster kidney. The results in Table 1 show that ovariectomy did not lower OAT activity in hamster kidney as it did in rat kidney $(5,16)$. Moreover, es- 
tradiol did not increase OAT activity in hamster kidney or liver even with prolonged treatment. These observations indicate that OAT induction by estradiol may be specific for rat kidney.

We have shown that OAT activity is highly significant in rat liver and in hamster liver and kidney, but the enzyme in these tissues is not inducible by estradiol. Evidently, OAT genome in these tissues is fully operative. To explain the non-inducibility, we propose that an estrogen receptor binding site on the chromatin specific for OAT induction may be reversibly (as in host kidney) or irreversibly (as in liver) blocked. Alternatively, the binding may require an unknown factor to direct the receptor to the specific site, and this site-directing factor is lacking in the non-responsive tissues. A more detailed discussion of this suggestion has been presented elsewhere (17).

\section{Acknowledgments}

This work was supported in part by a grant from The University of Michigan Cancer Research Institute.

\section{References}

1. Jensen, E.V. and DeSombre, E.R. (1972) In: Biochemical Actions of Hormones (G. Litwack, ed.) 2 , p. 215-255. Academic Press, New York.

2. Katzenellenbogen, B.S. and Gorski, J. (1975) In: Biochemical Actions of Hormones (G. Litwack, ed.) 3, p. 188-243. Academic Press, New York.

3. Schimke, R.T., McKnight, G.S. and Shapiro, D.J. (1975) In: Biochemical Actions of Hormones (G. Litwack, ed.) $\underline{3}$, p. 2.45-269. Academic Press, New York.

4. Rosen, J.M. and O'Malley, B.W. (1975) In: Biochemical Actions of Hormones (G. Litwack, cd.) 3, p. 271-315. Academic Press, Now York.

5. Wu, C. (1976) In: Control Mechanisms in Cancer (W.E. Criss, T. Ono, and J.R. Sabine, eds.) p. 125-138. Raven Press, New York.

6. Wu, C. (1978) Biochem. Biophys. Res. Commun. 82, 782-786.

7. Katzenellenbogen, J.A., Johnson, H.J. and Carlson, K.E. (1973) Biochemistry $\underline{12}, 4092-4099$.

8. Zava, D.T., Harrington, N.Y. and McGuire, W.L. (1976) Biochemistry $15,4292-4297$.

9. Lowry, O.H., Rosebrough, N.J., Farr, A.L. and Randall, R.J. (1951) J. Biol. Chem. 193, 265-275.

10. Burton, K. (1956) Biochem. J. 62, 315-322.

11. Li, J.J., Talley, D.J., Li, S.A. and Villee, C.A. (1974) Endocrinology 95. $1134-1141$.

12. Anderson, J., Clark, J.H. and Peck, E.J., Jr. (1972) Biochem. J. 126. $561-567$.

13. Ip, M.M., Chee, P.Y. and Swick, R.W. (1974) Biochim. Biophys. Acta $354,29-38$.

14. Wu, C. (1973) Internat. J. Cancer $11,438-447$.

15. Wu, C. (1973) Bot. Bull. Academia Sinica 14, 115-124.

16. Herzfeld, A. and Knox, W.E. (1968) J. Biol. Chem. 243, 3327-3332.

17. Wu, C. (1978) XII Internat. Cancer Congress, Abstracts 1, 210. 